\title{
PELATIHAN SAINS TEKNOLOGI KENDALI KENDALI JARAK JAUH MENGGUNAKAN SMARTPHONE DAN BLUETOOTH DI PONDOK PESANTREN AL FUSHA
}

\author{
Wahyu Widiyanto ${ }^{1}$, Candra Wahyu Sportyawan ${ }^{1}$, Tutut Indah Setyani ${ }^{1}$ \\ ${ }^{1}$ Jurusan Teknik Mesin, Program Studi Diploma 2 Teknik Mesin \\ Politeknik Negeri Bandung
}

Email: wahyu.widiyanto.pdd@polban.ac.id

\begin{abstract}
Abstrak
Jumlah pondok pesantren di Kabupaten Pekalongan pada tahun 2014 tercatat sebanyak 51 pondok pesantren. Salah satunya Pondok Pesantren Al Fusha terletak di Desa Rowocacing, Kec. Kedungwuni, Kab. Pekalongan yang merupakan Pondok Pesantren Terpadu. Santri Pondok Pesantren Al Fusha selain mempelajari ilmu agama, juga dibekali dengan beberapa kegiatan ekstrakulikuler. Tetapi belum ada pembelajaran ataupun kegiatan tentang penerapan sains dan teknologi kendali otomatis. Padahal sains dan teknologi kendali otomatis telah menjadi komponen penting dalam industri dan kehidupan manusia. Salah satunya adalah pembuatan sistem kendali jarak jauh menggunakan smartphone dan modul bluetooth berbasis kendali arduino. Sistem tersebut dipilih untuk mencegah meningkatnya tindak pencurian kendaraan bermotor secara tepat. Pada program pengabdian kepada masyarakat ini menggunakan metode pelatihan dan melalui beberapa tahapan. Kegiatan pelatihan ini dilaksanakan selama 4 hari dan bertempat di lingkungan Pondok Pesantren Al Fusha. Pelatihan ini menghasilkan modul pelatihan, trainer sistem kendali dan proses pelatihan. Modul pelatihan yang telah dibuat dan diterapkan pada pelatihan ini dapat dinilai baik, hal ini terbukti pada tingkat tercapainya pelatihan ini. Kegiatan pelatihan menunjukan adanya peningkatan hasil belajar peserta pelatihan sebesar 63,64\% mencapai KKM dan nilai rata-rata kelas 76,93. Berdasarkan analaisa dengan metode T-Test menunjukan dengan dilakukannya pelatihan mampu meningkatkan pengetahuan dan keterampilan peserta pelatihan.
\end{abstract}

Kata kunci: Pondok Pesantren, Sistem Kendali, Arduino, Smartphone, Modul Bluetooth

\section{PENDAHULUAN}

Kabupaten Pekalongan dijuluki juga sebagai Kota Santri. Jumlah pondok pesantren di Kabupaten Pekalongan pada tahun 2014 tercatat sebanyak 51 pondok pesantren [1]. Pada saat ini hampir semua Pondok Pesantren yang tadinya adalah pesantren salaf murni bertransformasi menjadi memformalisasi pendidikannya. Jadi Pondok Pesantren membuka pemondokan bagi pelajar dan mahasis- 
DIFUSI

Volume 3, No.2 Juli 2020

wa ataupun suatu Pondok Pesantren juga membuka sebuah sistem pendidikan dan madrasah. Diharapkan pesantren dapat memfungsikan dirinya sebagai lembaga tafaqquh fi al-din sekaligus lembaga yang mampu melahirkan intelektual ulama dan ulama intelektual [2].

Salah satu Pondok Pesantren di Pekalongan adalah Pondok Pesantren $\mathrm{Al} \mathrm{Fu-}$ sha. Pondok pesantren Al Fusha merupakan Pondok Pesantren Terpadu SMP - SMA - SMK. Pondok Pesantren Al Fusha merupakan Yayasan Pondok Pesantren yang berada di Desa Rowocacing, Kecamatan Kedungwuni, Kabupaten Pekalongan. Jumlah santri Pondok Pesantren Al Fusha pada tahun 2019 tercatat sebanyak 1275 santri terdiri dari 591 satriwan dan 684 santriwati. Pondok Pesantren Al Fusha selain mengajarkan ilmu agama, juga membekali para santri dengan beberapa kegiatan ekstrakulikuler seperti, pramuka, pencak silat/bela diri, marching band, dan sebagainya. Tetapi belum ada pembelajaran ataupun kegiatan tentang penerapan sains dan teknologi kendali otomatis. Serta di lingkungan Pondok Pesantren Al Fusha juga belum memiliki fasilitas penunjang pembelajaran sains dan teknologi otomatis. Faktor dana merupakan alasan belum adanya fasilitas penunjang tersebut. Padahal sains dan teknologi kendali otomatis telah menjadi komponen penting dalam industri dan kehidupan manusia sehari-hari.

Saat ini hampir dalam setiap aktifitas manusia, Sains dan teknologi kendali otomatis menjadi kebutuhan yang tidak dapat terhindarkan, seperti sistem otomasi pada pemanas air, injeksi bahan bakar pada kendaraan bermotor, kunci keyless pada kendaraan bermotor, dan masih banyak yang lainnya. Ini merupakan peluang usaha atau keahlian bagi para santri untuk menjadi technopreneurship.

Terlebih lagi Presiden Joko Widodo punya harapan besar terhadap pesantren. Dia berharap pondok-pondok pesantren di Tanah Air merespons persaingan global dengan baik [3]. Presiden menginginkan santri di Indonesia memiliki keterampilan dan skill yang tinggi sehingga mampu berkompetisi dengan negara lain [4]. Langkah - langkah yang dapat meningkatakan ketrampilan dan skill adalah dengan diadakannya pelatihan, workshop, seminar dll secara tepat. Pelatihan dan workshop tentang sains dan teknologi kendali otomatis sangat tepat pada era modern ini.

Upaya memperkenalkan Sains dan teknologi dapat dilakukan dengan berbagai metode, diantaranya dengan memperkenalkan dasar-dasar robotika, selain itu proses pembelajaran dapat dilakukan secara fleksibel, praktis dan menarik. Banyak peluang penerapan sains teknologi kendali otomatis. Salah satunya adalah peluang penerapan teknologi kendali jarak jauh kunci kendaraan bermotor. Berdasarkan data dari Badan Pusat Statistik (BPS), selama 5 tahun dari tahun 2007 sampai 2017 jenis kendaraan bermotor yang paling pesat pertumbuhannya adalah sepeda motor [5]. Sesuai dengan penelitian yang dilakukan oleh Herwangi dkk peran sepeda motor sangat besar untuk kegiatan-kegiatan rutin seperti bekerja dan bersekolah [6]. Data BPS pada buku laporan Statistik Kriminal 2018 menunjukan jumlah kasus pencurian kendaraan bermotor dari tahun 
DIFUSI

Volume 3, No.2 Juli 2020

2015 - 2017 sebanyak 38.389, 37.871, dan 35.226 [7].

Banyaknya kasus pencurian kendaraan bermotor perlu dilaksanakan upaya untuk menurunkan angka kasus tersebut. Pencegahan adalah solusi yang baik. Berkembangnya teknologi motor berfitur keyless pada sepeda motor baru bisa mencegah terjadinya tindak pencurian [8]. Hal ini dikarenakan untuk menghidupkan kelistrikan motor harus diaktifkan melalui remot dan sudah tidak memerlukan lubang kunci [9]. Teknologi keyless saat ini hanya ada pada sepeda motor dengan varian tertinggi dan berharga mahal. Sepeda motor lama dan varian terendah belum memiliki teknologi ini. Jadi, sepeda motor lama dan varian terendah masih sangat rawan terjadi tindak pencurian.

Teknologi kendali jarak jauh menggunakan smartphone dan fasilitas bluetooth untuk menyalakan dan mematikan kelistrikan pada sepeda motor bisa juga digunakan untuk mencegah terjadinya tindak pencurian kendaraan bermotor. Jadi sepeda motor yang belum memiliki fitur teknologi keyless bisa menggunakan teknologi kendali jarak jauh tersebut.

Pengetahun mengenai Sains dan teknologi kendali otomatis perlu diperkenalkan kepada masyarakat khususnya para santri. Tujuan dari pelatihan ini adalah didapatkan sebuah modul pelatihan/pembelajaran pemprograman mikrokontroler arduino dan para santri mampu memprogram dan menginstalasi teknologi kendali otomatis pada penerapan kendali jarak jauh menggunakan smartphone dan bluetooth.

\section{METODE}

Pada program pengabdian kepada masyarakat ini menggunakan metode pelatihan dan melalui beberapa tahapan. Adapun tahapan palatihan ini ditunjukan pada diagram alir Gambar 1.

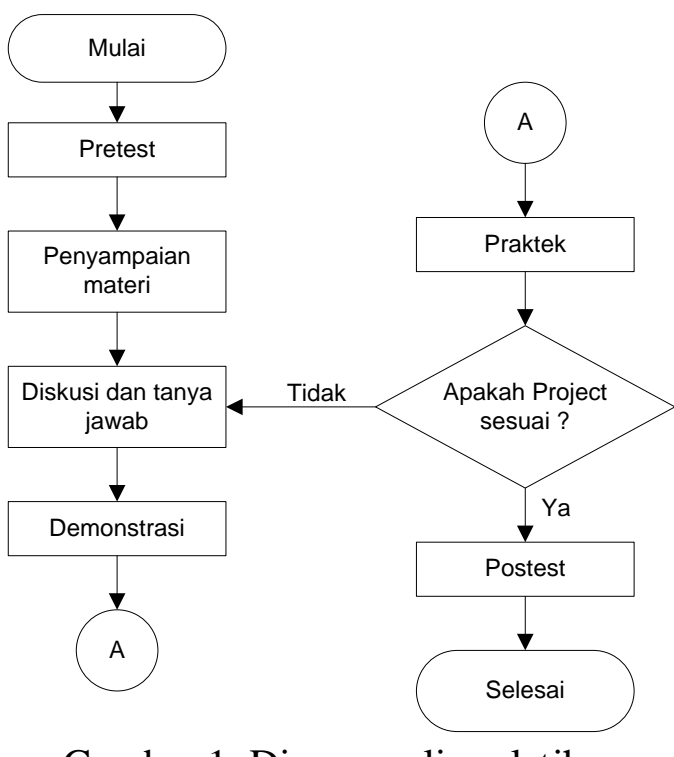

Gambar 1. Diagram alir pelatihan

Beberapa metode yang digunakan dalam pelaksanaan kegiatan pengabdian kepada masyarakat ini adalah sebagai berikut.

1. Metode ceramah digunakan untuk menyajikan materi yang bersifat pemahaman dan pengetahuan teoritis mengenai perangkat keras dan perangkat lunak sistem kendali yang digunakan.

2. Metode tanya jawab dan diskusi; digunakan untuk mendapatkan sejauh mana pengetahuan dan memotivasi peserta pelatihan mengenai ruang lingkup pengetahuan sains dan teknologi kendali otomatis berbasis Arduino Uno bagi Ustadz/Guru dan para santri. 
3. Metode demonstrasi; digunakan untuk memperlihatkan tata cara, tips dan trik mudah dalam menggunakan, merakit, memprogram dan mengoperasikan perangkat kendali berbasis Arduino Uno.

4. Interaksi langsung; metode ini dibuat dengan bentuk workshop, jadi tidak hanya sebatas pada teoritis saja tetapi juga dengan praktik penggunaannya secara langsung.

5. Metode evaluasi; test yang diberikan pada awal dan akhir pelatihan agar didapatkan data daya serap peserta pelatihan pada materi yang telah disampaikan.

Kegiatan pelatihan ini dilaksanakan selama 4 hari dan dilaksanakan bertempat di lingkungan Pondok Pesantren $\mathrm{Al} \mathrm{Fu-}$ sha. Adapun jadwal dalam melaksanakan program ini secara lebih rinci ditunjukan pada Tabel 1.

Tahapan metode evaluasi pada kegiatan pelatihan ini mencakup awal dan akhir kegiatan. Pretest dilakukan kepada peserta pelatihan agar mengetahui kemampuan awal, terutama pemahaman dan pengetahuan tentang sains dan teknologi kendali otomatis secara umum. Hasil evaluasi, berguna untuk mendapatkan data posisi awal pemberian materi supaya materi yang disampaikan dapat sesuai dengan kemampuan awal peserta pelatihan. Postest diberikan diakhir pelatihan kepada peserta untuk mengetahui hasil dari pemahaman tentang sains dan teknologi kendali otomatis. Dalam evaluasi ini kriteria keberhasilan diukur dengan meningkatnya kemampuan membuat system kendali jarak jauh menggunakan smartphone dan modul Bluetooth berbasis arduino uno. Sistem
Tabel 1. Rincian jadwal pelaksanaan kegiatan

\begin{tabular}{|c|c|c|c|c|}
\hline \multirow{2}{*}{ Uraian Kegiatan } & \multicolumn{4}{|c|}{$\begin{array}{c}\text { Jadwal } \\
\text { Kegiatan }\end{array}$} \\
\hline & 1 & 2 & 3 & 4 \\
\hline $\begin{array}{l}\text { Persiapan kegiatan dan } \\
\text { pengumpulan data }\end{array}$ & $\sqrt{ }$ & & & \\
\hline $\begin{array}{l}\text { Persiapan alat dan bahan pela- } \\
\text { tihan }\end{array}$ & $\sqrt{ }$ & & & \\
\hline Pembuatan modul ajar & $\sqrt{ }$ & & & \\
\hline $\begin{array}{l}\text { Pembukaan pelatihan dan } \\
\text { pengenalan PDD Politeknik }\end{array}$ & $\sqrt{ }$ & & & \\
\hline Negeri Bandung & & & & \\
\hline Pretest & $\sqrt{ }$ & & & \\
\hline $\begin{array}{l}\text { Pendahuluan pengenalan } \\
\text { mikrokontroler Arduino dan } \\
\text { software Arduino IDE }\end{array}$ & $\sqrt{ }$ & & & \\
\hline $\begin{array}{l}\text { Pembuatan program penyalaan } \\
\text { LED }\end{array}$ & $\sqrt{ }$ & & & \\
\hline Pembuatan program animasi & $\sqrt{1}$ & & & \\
\hline LED & $v$ & & & \\
\hline Review materi & $\sqrt{ }$ & & & \\
\hline $\begin{array}{l}\text { Penjelasan dan penerapan } \\
\text { aplikasi Input - Ouput digital } \\
\text { Arduino }\end{array}$ & & $\sqrt{ }$ & & \\
\hline $\begin{array}{l}\text { Penjelasan dan penerapan } \\
\text { aplikasi Input - Ouput analog } \\
\text { Arduino }\end{array}$ & & $\sqrt{ }$ & & \\
\hline Review materi & & $\sqrt{ }$ & & \\
\hline $\begin{array}{l}\text { Membuat thermometer digital } \\
\text { menggunakan sensor } \\
\text { dan ditampilkan di } 35 \\
\text { monitor }\end{array}$ & & & $\sqrt{ }$ & \\
\hline $\begin{array}{l}\text { Membuat thermometer digital } \\
\text { menggunakan sensor LM35 dan } \\
\text { ditampilkan di LCD }\end{array}$ & & & $\sqrt{ }$ & \\
\hline Review Materi & & & $\sqrt{ }$ & \\
\hline $\begin{array}{l}\text { Menjelaskan pembuatan software } \\
\text { android menggunakan MIT App } \\
\text { Inventor }\end{array}$ & & & & $\sqrt{ }$ \\
\hline Membuat 31ystem kendali & & & & $\sqrt{ }$ \\
\hline Bluetooth dengan modul HC-05 & & & & v \\
\hline Review materi & & & & $\sqrt{ }$ \\
\hline Posttest & & & & $\sqrt{ }$ \\
\hline Penutup & & & & $\sqrt{ }$ \\
\hline
\end{tabular}

kendali jarak jauh menggunakan smartphone dan modul bluetooth $\mathrm{CH}-05$ berbasis mikrokontroler Arduino Uno menggunakan beberapa komponen, diantaranya : 
DIFUSI

Volume 3, No.2 Juli 2020

1. Smartphone android

2. Mikrokontroler arduino uno

3. Modul relay

4. Modul Bluetooth $\mathrm{CH}-05$

Adapun skema rangkaian dari system tersebut ditunjukan pada Gambar 2.

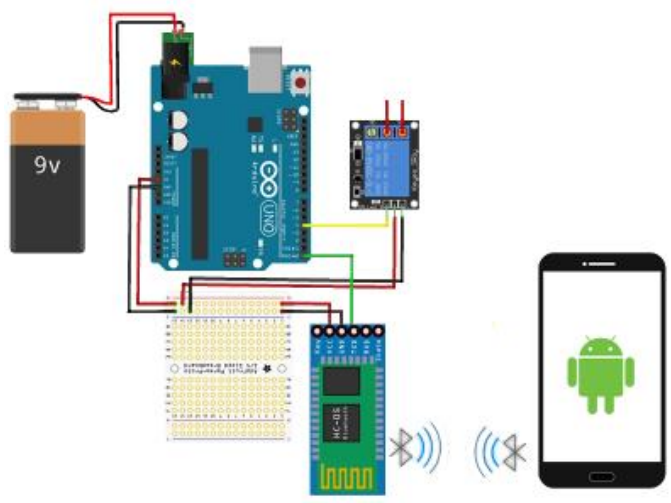

Gambar 1. Skema system kendali smartphone dan modul bloetooht berbasis arduino uno

\section{HASIL DAN PEMBAHASAN}

Berdasarkan pengabdian kepada masyarakat mengenai pelatihan sains teknologi kendali otomatis pada penerapan kendali jarak jauh menggunakan smartphone dan bluetooth di pondok pesantren Al Fusha yang telah dilakukan, diperoleh hasil dan pembahasannya pada masing-masing tahap pembuatan modul pelatihan dan proses pelatihan adalah sebagai berikut.

\section{Pembuatan Modul Pelatihan}

Modul adalah termasuk bahan ajar yang berbentuk tercetak dapat digunakan oleh peserta didik sebagai media untuk belajar secara mandiri serta seorang pengajar/trainer menggunakan modul untuk menyampaikan materi pada peserta didik secara sistematis.

Sebelum membuat modul pelatihan, ada beberapa kegiatan yang dilakukan. Pertama melakukan wawancara kepada Bapak Andi selaku kepala sekolah SMK di pondok pesantren Al Fusha . Dari wawancara tersebut didapatkan materi materi yang dibutuhkan oleh pengajar dan siswa pada saat Program Pengabdian kepada Masyarakat ini. Materi - materi yang dibutuhkan adalah:

a. Pengenalan Arduino;

b. Penyalaan LED;

c. Program Dasar (Animasi LED);

d. Akses Input;

e. Aplikasi Termometer Digital (ADC-PWM);

f. Kendali Buetooth.

Materi yang dibutuhkan terakhir adalah kendali bluetooth yang aplikasinya pada sistem penyalaan dan mematikan stater kendaraan bermotor. Kebetulan di pondok pesantren Al Fusha memiliki smk dengan jurusan teknik kendaraan ringan sehingga dapat menunjang pengembangan teknologi di bidang tersebut. Dengan begitu ekstra kulikuler yang rencananya akan dibuka dapat terarah langsung ke aplikasi yang juga dapat dibuat produk pengembangan di SMK yang ada di pondok pesantren Al Fusha.

Kontroler yang digunakan adalah Arduino UNO karena lebih familiar dan cukup teruji ketangguhannya untuk proses belajar. Fasilitas yang ada pada Arduino UNO juga kengkap dengan pin analog dan pin digital dan juga memiliki pi output PWM. Pemrograman Arduino menggunakan teks bahasa $\mathrm{C}$ yang mudah dipahami. Disamping itu disupport 
DIFUSI

Volume 3, No.2 Juli 2020

banyaknya library yang dapat digunakan untuk menunjang pembuat program sistem. Software yang digunakan adalah software Arduino IDE yang dapat didownload gratis dari situs arduino.cc.

Adapun materi - materi yang disajikan dalam modul pelatihan ini (Gambar 3) antara lain :

a. Pengenalan Arduino

i. Pengenalan dasar dan board

ii. Instalasi Arduino IDE

b. Penyalaan LED

i. Teori dasar

ii. Rangkaian

iii. Program

c. Program Dasar (Animasi LED)

i. IF ...ELSE

ii. While

iii. Kondisi TRUE and FALSE

iv. Array

d. Akses Input

i. Push Button

ii. Potensiometer-Led(ADCPWM)

iii. Millis

e. Termometer Digital

i. Serial Monitor

ii. LCD

f. Kendali Bluetooth

i. Rangkaian

ii. Program Software Arduino IDE

iii. Program Software MIT App Inventor

\section{Alat Pelatihan}

Penyiapan alat pelatihan disesuaikan dengan materi-materi yang terdapat pada modul pelatihan yang telah dibuat. Berdasarkan materi-materi pelatihan yang telah dibuat maka didapatkan daftar kebutuhan bahan alat pelatihan sains teknologi kendali otomatis pada penerapan kendali jarak jauh menggunakan smartphone dan bluetooth.

Berikut daftar kebutuhan bahan dan komponen untuk alat pelatihan sains teknologi kendali otomatis pada penerapan kendali jarak jauh menggunakan smartphone dan bluetooth:

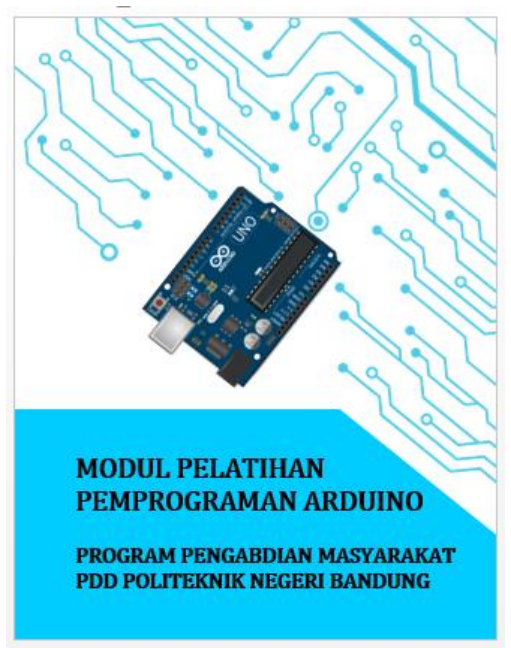

Gambar 2. Cover modul pelatihan [10]

a. Komponen :

i. Arduino UNO R3

ii. LED

iii. Resistor

iv. Push Button

v. Potensiometer

vi. LCD $16 x 2$

vii. Modul Relay

viii. Modul Bluetooth HC-05

ix. PC Komputer

x. Kabel Transfer USB

xi. Project Board

xii. Box

b. Software

i. Arduino IDE

ii. App Inventor

Selain komponen dan bahan yang tersebut diatas juga memanfaatkan aplikasi 
DIFUSI

Volume 3, No.2 Juli 2020

whatsapp untuk komunikasi bimbingan latihan mandiri yang dilakukan pengajar maupun siswa. Jadi selain tatap muka, proses pelatihan juga dilakukan dengan penugasan dan bimbingan online yang dilakukan untuk memonitor perkembangan pelatihan yang dilaksanakan.

\section{Proses Pelatihan}

Bermula dari kebutuhan akan kompetensi keahlian sistem robotik oleh siswa SMK, maka dilaksanakan Program Pengabdian kepada Masyrakat (PPM) tentang pelatihan sains teknologi kendali otomatis pada penerapan kendali jarak jauh menggunakan smartphone dan bluetooth. Sasaran pada pelatihan ini adalah siswa - siswi/santri dan guru/ustadz di lingkungan pondok pesantren Al Fusha .

Program Pengabdian kepada Masyarakat dengan bentuk pelatihan sains teknologi kendali otomatis pada penerapan kendali jarak jauh menggunakan smartphone dan bluetooth telah dilaksanakan dalam waktu 4 hari yaitu dari Senin, 19 Agustus 2019 hingga Kamis, 22 Agustus 2019 yang dimulai pukul 07.30 WIB sampai pukul 13.00 WIB dengan jumlah peserta 10 Guru dan 30 siswa - siswi baik SMA maupun SMK. Pelaksanaan pelatihan ini bertempat di pondok pesantren Al Fusha yang beralamat $\mathrm{Jl}$. Raya Rowocacing Pakisputih, Rowocacing Cilik, Rowocacing, Kec. Kedungwuni, Pekalongan, Jawa Tengah. Waktu pelaksanaan ditentukan oleh pihak mitra. Hal ini dikarenakan peserta pelatihan kelas 12 pada waktu pelaksanaan pelatihan ini berlangsung, juga sedang melaksanakan pemadatan materi sekolah untuk persiapan menghadapi Ujian $\mathrm{Na}$ sional. Jadi yang seharusnya waktu pelaksanaan pelatihan dilaksanakan selama enam hari, maka disepakati dipadatkan menjadi empat hari.

Pelatihan ini dilaksanakan dengan melibatkan 5 mahasiswa dan 2 dosen. Mahasiswa dilibatkan dalam pelatihan ini sebagai instruktur pelatihan. Sedangkan dosen dalam pelatihan ini sebagai nara sumber. Materi yang disampaikan menggunakan laptop dan infocus, dengan ditambahkan panduan berupa modul pelatihan yang telah dibagikan pada masing - masing peserta pelatihan. Pada pelatihan ini menggunakan model pembelajaran kooperatif tipe Student Teams Achievement Division (STAD). Penyampaian materi teori dilakukan menggunakan metode ceramah dan dilanjutkan metode diskusi (Gambar 4). Hal ini dilakukan agar peserta pelatihan dapat lebih mudah dalam menangkap materi yang disampaikan oleh nara sumber. Sedangkan pada saat praktik metode yang digunakan adalah metode demonstrasi. Dimana nara sumber menyampaikan materi dengan cara memperagakan dan mempertunjukan secara langsung cara memprogram dan menginstalasi mikrokontroler arduino dengan device yang lain. Pada sesi praktik dibantu instruktur untuk melaksanakan pendampingan secara langsung pada peserta pelatihan yang sedang mempraktikkan materi pada komputer dan alat pelatihan. Instruktur sebagai pendamping berkewajiban membantu menjelaskan materi dikomputer dan alat pelatihan kepada peserta pelatihan mengenai hal-hal yang belum dipahami atau yang perlu ditanyakan. 
Pada pelatihan ini dibagi menjadi dua sesi yaitu sesi tatap muka dan penugasan dan bimbingan online. Sesi tatap muka ini merupakan pelatihan cara merancang sebuah sistem sederhana berbasis arduino menggunakan software dan trainer. Software komputer yang digunakan adalah Arduino ide. Software ini dipilih karena mudah dipahami dan menggunakan bahasa $\mathrm{C}$ yang sering digunakan untuk memprogram arduino serta hasil perancangan langsung disimulasikan pada trainer. Materi - materi perancangan menggunakan software arduinoide sudah ada dimodul pelatihan.

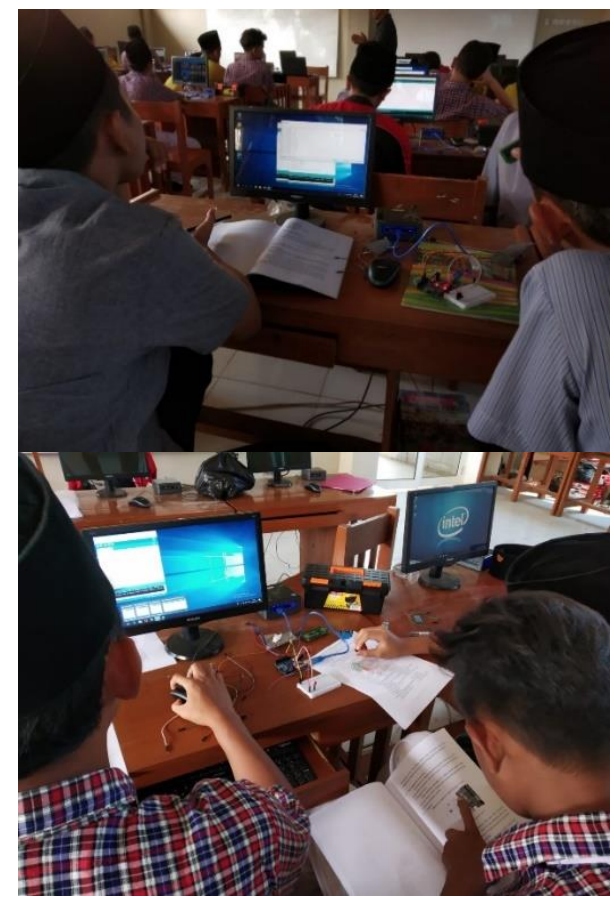

Gambar 3. Peserta pelatihan merancang sistem

Pada sesi penugasan dan bimbingan online, peserta pelatihan mengerjakan tugas yang telah disediakan. Pada proses pengerjaan tugas dilakukan juga bimbingan memalui whatsapp dengan instruktur dan pembimbing dari dosen.
Pada proses belajar penerapan sistem setelah pelatihan selasai juga masih dibuka bimbingan online via whatsapp dengan pelatih dari dosen. Melalui skema pelatihan ini peserta didik dapat melakukan pemrograman dan instalasi sistem berbasis arduino.

Dari hasil pengamatan pelatihan sains teknologi kendali otomatis pada penerapan kendali jarak jauh menggunakan smartphone dan bluetooth, terlihat peserta pelatihan mengikuti pelatihan dengan sangat antusias. Hal ini juga terlihat pada saat peserta pelatihan belum jelas dengan yang disampaikan oleh nara sumber, peserta pelatihan langsung menanyakan kepada instruktur pendamping.

Dari keseluruhan materi yang disampaikan, diharapkan dapat diserap dan dimengerti oleh peserta pelatihan, yang nantinya dapat dimanfaatkan untuk bekal bekerja dan berwirausaha (bagi siswa) dan dapat disampaikan ke siswasiswinya (bagi guru ekstra kulikuler).

\section{Hasil Belajar}

Dalam pelaksanaan pelatihan, untuk mengukur hasil belajar dilaksanakan dua kali tes pada ranah kognitif peserta pelatihan. Pre-test dilaksanakan pada awal pelatihan sebelum pelaksanaan kegiatan, tes tersebut bertujuan agar diketahui kemampuan awal peserta pelatihan sebelum dilakukan tindakan. Selanjutnya post-test dilaksanakan di akhir pelatihan setelah tindakan (kegiatan pelatihan) selesai dilaksanakan. Post-test memiliki tujuan agar diketahui seberapa besar peningkatan hasil belajar ranah kognitif peserta pelatihan setelah selesai dilaku- 
DIFUSI

Volume 3, No.2 Juli 2020

kan tindakan. Bentuk pre-test dan posttest adalah soal pilhan ganda dengan jumlah soal sebanyak 30 soal.

Peserta pelatihan dapat disebut tuntas dalam menguasai materi jika nilai yang didapatkan mencapai kriteria ketuntasan minimal (KKM) yang telah ditentukan yaitu $\geq 75$. Pada pelatihan ini menggunakan model pembelajaran kooperatif tipe Student Teams Achievement Division (STAD) yang mana mengatakan Hasil Belajar berhasil meningkat pada peserta pelatihan jika jumlah minimal $75 \%$ dari seluruh peserta pelatihan mendapatkan nilai $\geq 75$. Pada pelatihan ini mendapatkan hasil nilai rata-rata kelas pada saat pre-test adalah 48,94. Sedangkan nilai rata-rata kelas pada saat post-test didapatkan nilai sebesar 76,97. Pada Tabel 2 menunjukan nilai ketuntasan peserta pelatihan dari Hasil Belajar.

Tabel 2. Hasil Belajar

\begin{tabular}{|c|c|c|c|c|}
\hline \multirow{2}{*}{$\begin{array}{c}\text { Kategori } \\
\text { Nilai }\end{array}$} & \multicolumn{2}{|c|}{ Pre-test } & \multicolumn{2}{|c|}{ Post-test } \\
\hline & $\begin{array}{c}\text { Freku } \\
\text { ensi }\end{array}$ & $\%$ & $\begin{array}{c}\text { Freku } \\
\text { Ensi }\end{array}$ & $\%$ \\
\hline Tunta & 0 & 0,00 & 14 & 63,64 \\
\hline $\begin{array}{l}\text { Tidak } \\
\text { tuntas }\end{array}$ & 22 & 100,00 & 8 & 36,36 \\
\hline Jumlah & 22 & 100 & 22 & 100 \\
\hline
\end{tabular}

Data dari Tabel 2 dapat juga dibuat dalam bentuk diagram batang, maka Hasil Belajar ranah kognitif peserta pelatihan akan terlihat pada Gambar 5. Data pada Tabel 2 dan diagram Gambar 5 menunjukan bahwa nilai peserta pelatihan dari pre-test dan post-test mengalami peningkatan. Dilihat dari jumlah peserta pelatihan yang mencapai KKM, pada nilai pre-test tidak ada yang mencapai KKM, sedangkan pada hasil post-test sebanyak 14 peserta pelatihan $(63,64 \%)$ mencapai KKM dan 8 peserta pelatihan $(36,36 \%)$ belum mampu mencapai KKM. Pada nilai rata-rata kelas mengalami peningkatan sebesar $28,03 \%$ yaitu pada saat pretest nilai rata-rata kelas 48,94 dan pada saat post-test nilai rata-rata kelas sebesar 76,93. Walaupun terjadi peningkatan jumlah siswa yang tuntas dan nilai rata-rata kelas, penerapan yaitu Model Pembelajaran Kooperatif Tipe Student Teams Achievement Division (STAD) untuk meningkatkan Hasil Belajar peserta pelatihan pada pelatihan ini belum berhasil karena jumlah peserta pelatihan yang mendapat nilai tuntas belum mencapai $75 \%$ dari jumlah peserta pelatihan dalam satu kelas.

Berikut hasil analisa data dari data pretest dan posttest menggunakan metode T-Test yang mana menggunakan nilai alpha $(\alpha)$ yaitu 0.05 , ditunjukan pada Tabel 3.

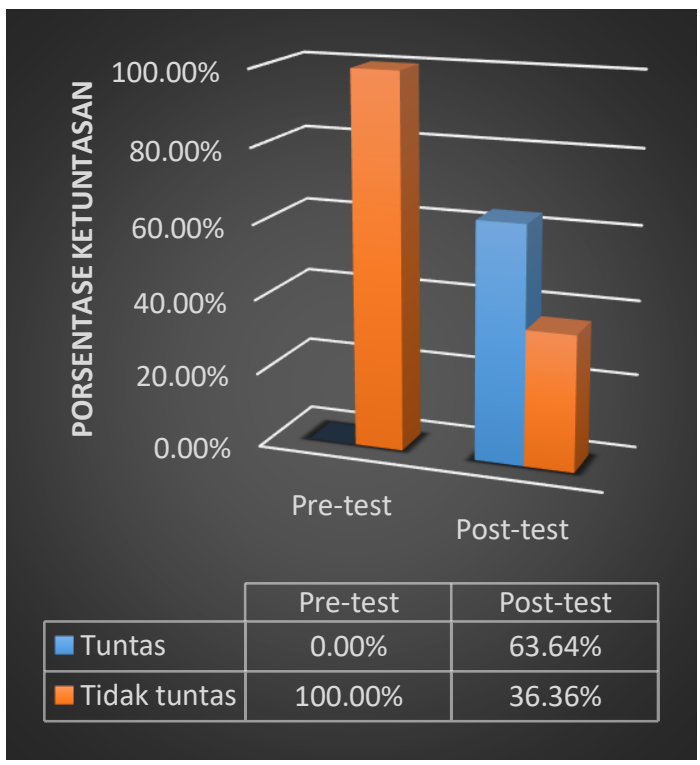

Gambar 4. Ketuntasan Hasil Belajar Tabel 3. t-Test: Paired Two Sample for Means 


\begin{tabular}{lll}
\hline & \multicolumn{1}{c}{ TEST } & POST-TEST \\
\hline Mean & 48.93939394 & 76.96969697 \\
Variance & 87.18133718 & 28.47522848 \\
Observations & 22 & 22 \\
Pearson Correlation & 0.070473039 & \\
Hypothesized Mean & 0 & \\
Difference & & \\
df & 21 & \\
t Stat & -12.6141017 & \\
P $(\mathrm{T}<=$ t) one-tail & $1.44247 \mathrm{E}-11$ & \\
$\mathrm{t}$ Critical one-tail & 1.720742903 & \\
$\mathrm{P}(\mathrm{T}<=\mathrm{t})$ two-tail & $2.88493 \mathrm{E}-11$ & \\
$\mathrm{t}$ Critical two-tail & 2.079613845 & \\
\hline
\end{tabular}

Tabel 3 menunjukan bahwa T-stat (t hitung) lebih kecil daripada $T$-chritical one tile ( $\mathrm{t}$ tabel) yaitu $-12.614<1.721$ dan p-value lebih kecil dari alpha $(\alpha)$ yaitu $1.442 \mathrm{e}-11<0.05$, sehingga dapat disimpulkan bahwa dengan dilakukannya pelatihan mampu meningkatkan pengetahuan dan keterampilan peserta pelatihan.

\section{KESIMPULAN}

Berdasarkan pembahasan dan pelaksanaan kegiatan ini, maka dapat disimpulkan :

1. Modul pelatihan yang telah dibuat dan diterapkan pada pelatihan peningkatan skill ini dapat dinilai baik, hal ini terbukti pada tingkat tercapainya pelatihan ini.

2. TIM PPM telah berhasil melaksanakan pelatihan sains teknologi kendali otomatis pada penerapan kendali jarak jauh menggunakan smartphone dan bluetooth bagi siswa pondok pesantren Al Fusha yang ditunjukan adanya peningkatan hasil belajar peserta pelatihan sebesar $63,64 \%$ mencapai KKM dan nilai rata-rata kelas 76,93.
3. Guru - guru dan siswa - siswi di SMA dan SMK di pondok pesantren Al Fusha memberikan tanggapan yang antusias pada pelatihan ini dilihat dari jumlah kehadiran dan respon saat pelatihan.

4. Analisa dengan metode T-Test menunjukan dengan dilakukannya pelatihan mampu meningkatkan pengagetahuan dan keterampilan peserta pelatihan yang ditunjukan dengan hasil $\mathrm{t}$ hitung $<\mathrm{t}$ tabel dan $\mathrm{p}$ value $<$ alpha $(\alpha)$.

Berdasarkan kesimpulan dan masukan dari pihak mitra, maka didapat saran bahwa :

a. Kegiatan lanjutan program pelatihan seperti ini perlu diadakan untuk materi selanjutnya.

b. Perlunya menambahkan waktu dalam pelaksanaan pelatihan PPM sehingga dapat menambah daya serap materi.

\section{UCAPAN TERIMAKASIH}

Program Pengabdian kepada Masyarakat ini didukung oleh dana DIPA Politeknik Negeri Bandung. Penulis mengucapkan terima kasih atas pendanaan yang telah diberikan.

\section{REFERENSI}

[1] M. Zulfa dan Mahbib, "RMINU Data Pesantren di Pekalongan," 15 Oktober 2014. [Online]. Available: http://www.nu.or.id/post/re$\mathrm{ad} / 55106 /$ rminu-data-pesantrendi-pekalongan. 
[2] A. Ta'rifin, Muhlisin, Maskhur dan M. Ula', "Formalisasi dan Transformasi Pendidikan Pesantren," Jurnal Penelitian, pp. 1-16, 2012.

[3] F. J. Kuwado, "Harapan Besar Jokowi ke Pondok Pesantren di Tengah Persaingan Global," 17 Juni 2016. [Online]. Available: https:// nasional.kompas.com/read/2016/0 6/17/08384741/harapan.besar.joko wi.ke.pondok.pesantren.di.tengah. persaingan.global. [Accessed 2 Mei 2019].

[4] T. Budi, "Ini Harapan Jokowi pada Seluruh Santri Tanah Air," 20 Oktober 2018. [Online]. Available:https://news.okezone.com/re$\mathrm{ad} / 2018 / 10 / 20 / 337 / 1966512 /$ iniharapan-jokowi-pada-seluruh-santri-tanah-air. [Accessed 2 Mei 2019].

[5] Badan Pusat Statistik, "Perkembangan Jumlah Kendaraan Bermotor Menurut Jenis, 1949-2017," 30 April 2019. [Online]. Available:https://www.bps.go.id/linkTa bleDinamis/view/id/1133.
[6] Y. Herwangi, I. Syabri and I. Kustiwan, "Peran dan Pola Penggunaan Sepeda Motor Pada Masyarakat Berpendapatan Rendah di Kawasan Perkotaan Yogyakarta," Jurnal Perencanaan Wilayah dan Kota, pp. 166-176, 2015.

[7] Badan Pusat Statistik, "Statistik Kriminal 2018," Badan Pusat Statistik, Jakarta, 2018.

[8] A. F. Indrawan, "Teknologi Motor Keyless yang Bikin Maling Motor Kesal," 31 Desember 2017. [Online]. Available:https://news .detik.com/berita/d3792481/teknologi-motor-keyless-yang-bikin-maling-motor-kesal.

[9] A. P. Niagara, "2 Fitur Kekinian untuk Dongkrak Keamanan Sepeda Motor," 24 Juli 2018. [Online].Available:https://kumparan.co $\mathrm{m}$ /@ kumparanoto/2-fitur-kekinian-untuk-dongkrak-keamanansepeda-otor27431110790551936.

[10] C. W. Sportyawan and W. Widiyanto, Modul Pelatihan Pemrograman Arduino, Pekalongan: Politeknik Negeri Bandung, 2019 